https://doi.org/10.18485/unislav.2017.ch19

371.3::811.161.1

930.85:004

\author{
ДРАГИЊА РАМАДАНСКИ* \\ Филозофски факултет Универзитета у Новом Саду \\ Нови Сад, Србија
}

\title{
МЕТОДИЧКЕ НЕДОУМИЦЕ СА ВРХА АЈСБЕРГА
}

\begin{abstract}
Како предавати руску књижевност данас, када смо оријентисани на екран, са којег нас запљускују сасвим противуречна мишљења? И студенти и професори су свесни методичког ћорсокака у коме се налазе. Мада је технолошка предност на страни студената, очекује се да наставник држи ситуацију под контролом. Одговор који покушавамо да изнађемо није песимистичан. Осим увида у данашњу праксу, он подразумева присећање на учитеље „пре мреже”, указивање на примере из садашњице као и сугестије за будућност.
\end{abstract}

Кључне речи: дигитална филологија, арбитрарна уџбеничка синтеза, глобални меганаратив, колекција специјалистичких приступа, историја тумачења датог корпуса

\begin{abstract}
„Филологија почиње од неповерења у реч. Почела је од изучавања мртвих језика, мада постоји и мртва књижевност, на живим језицима. Књиге нам не одговарају на питања која је себи постављао писац, већ на она која смо у стању сами себи да поставимо, а то су често веома различите ствари" (Гаспаров 2001, 99).
\end{abstract}

Како, предавати, руску, књижевност, данас? Сваки део ове реченице је упитан, и полемичан, у односу на јуче. Набусити одговор би гласио: Никако. Не предавати. Неруску. Антикњижевност. Племенити глагол традирања изгубио је своју ауру, преносе се само голе и шокантне информације, из сфере вечитог презента неке нове екумене, и њеног нарцистичког монолога. Анахроно је возити се кочијама од Сенте до Туле: светска мрежа нас у хипу пребацује на жељену дестинацију. Без намере да ово буде антијубиларни антитрибјут, нужно смо усредсређени на екран величине длана, са којег нас санкционише палац виртуелног мнења... Ваљало би направити софтвер са командом: непоновљиво, јединствено, нечувено. Танка црвена нит небаждареног, невиног себства

*draginjaramadanski@gmail.com 
кроз масу сведоступног, безброј пута преме́шеног интерте(к)ста. Нешто од чега се може изнова почети одбројавање, ма макар и посве арбитрарно (попут студентског уверења да је Чичиков најпозитивнији лик руске књижевности, или тврдње студенткиње-дарвинисткиње да су Руси постали од - руског мајмуна).

Јер, шта заправо баштинимо од својих учитеља? То није само наш заједнички, немерљиво узбудљив предмет изучавања, већ и шаролики однос према том и таквом предмету. Тај однос је, опет, мање у намери а више у омакнућу, и најбоље се уж и в а са стране, у сфери оног што бисмо могли назвати хищный ілазомер, незајажљива зорност младости. Она је (далеких седамдесетих) могла да примети затомљену еруптивност и лепорекост професора Бабовића (оно када се загризете за усну и руком забаците прамен са чела); обавезујућу узлетелост (да ли ћемо икада сустићи те недосежне тумачењске хоризонте) професора Јовановића; дамски робусне импровизације професорице Стојнић; обуздавање интерпретативне самовоље професора Сибиновића; занесеност у одлучивању за јеретичко младог Матијашевића; милозвучно, певљиво лице рускости под диригентском палицом Андреја Тарасјева; госпарску љубав према археославистици професора Богдана Терзића; способност за ретка али тим лепша изненађења његовог презимењака, Терзић Алексадра; седу фризуру a la garçon и мајчинску сусретљивост Драгиње Голубовић; дар за достојанствени силазак са сцене Лидије Шпис Мирни; невидљиво тиктакање џепног сата Кирила Свинарског у сутерену факултета; мирољубиву коегзистенцију професуре и уметничког самоискушавања Зорана Божовића.. Тајновидци и шамани са, нама недоступним, ресурсима, ексклузивним сведочењима, тајнописом митских кухињских сашаптавања. Окамине, диносауруси, изложени безобирном студентском ејџизму. У свом ручно плетеном џемперу диктира нам, тако, професор Бошковић своју индоевропску абракадабру, при чему га спопада смех налик јецању...

Оно што је обележило наш давнашњи сусрет била је, наиме, ситуација идеолошког лома. Обраћали су нам се наши професори из дубоке прошлости својих запустелих завичаја, из суморне стварности титоистичког кетманства, из сопственог идеолошког подземља. Наше адолесцентски плитко сећање чувало је тек слетове, уранке, ватромете, троуглу мараму црвене боје, међу толиким троугловима на свету. Овде и нехотице прелазимо на некакву прозу, док се зене професора Јовановића „мачорски" жаре...

Чини се да је тада свака ексцентрика доживљавана као културолошки препознатљива јавка. Понекад је било довољно одговорити питањем на питање, употребити question tag, дрзнути се на чувено бродскијанско „да?" па да се и студент и професор осете ословљенима на 
прави начин. Није важно што нисте знали шта повезује Тулу и самовар: било је пресудно да по нечему личите на Оњегина или Татјану.

Ондашње уџбенике данас је немогуће читати без историјског преосмишљавања. Доказ више да дискурс мудрости не стаје ни на чију страну, да је веран понајпре поднебљу и пејзажу, на начин Тихої Дона (ма ко да га је писао). ${ }^{1}$

Русистика моје младости подсећала је на религиозну праксу, где се проучавао канон одабраних писаца, и помним читањем се потврђивала њихова величина. Таква сакрализација канона довела је до тога да је велики део књижевног масива остао ван пажње професора и студената, напросто непрочитан. Данас је, пак, постало јасно да канонски аутори не постоје без оних других, минорних. Сада нас занима књижевност у целини. Акценат се ставља на контекстуализацију књижевног текста, у оквирима других дискурзивних структура, историје идеја, религиозних и политичких појмова. Помно читање „ред по ред” замењено је методом читања из друге руке, на даљину. Уместо једног сувереног канона имамо више мањих (женски, квир, постколонијални). Актуелна критика се изједначава са нечитањем, са удаљавањем од текста. Занемаримо ли констернирану реакцију и отворену могућност карикирања (Адријана

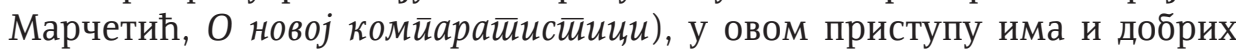
страна.

Помно читање и палета бриљантних интерпретација је канда иза нас - актуелни изазов је провера утиска на глобалном плану, у свету који посматрамо као систем (world-system analysis, концепт Имануела Валерштајна). Ово је прилика и да се сетимо да је пионир квантитативног приступа текстовима, у светлу аналогије између природе и књижевности, управо руски научник Борис Исакович Јархо (1889-1942). Као члан Московског лингвистичког кружока, он у периоду 1935-1938, током прогонства у Омску, пише дело Методология точного литературовеgения (објављено фрагментарно 1969. године). Његова истраживања настављена су сада на пољу дигиталне хуманистике, где се десио сусрет еволуционе теорије и књижевних феномена.

Књижевна историја напушта изучавање чистих форми и окреће се проучавању књижевности као институције (Франко Морети). На тај начин се уочавају „наративна тржишта”, која су уједно и мотор књижевне еволуције, смештен у различите зоне (Имануел Валерштајн). Чини се да је академски предмет Руска кулйура израз те методичке тежње да се књижевност и њена историја уграде у „свет као систем”, унутар једне

${ }^{1}$ Вероватно је слична мисао водила и Дмитрија Бикова, који је одскора увео термин јужно-руска књижевности, не би ли из другог ракурса осмотрио књижевни локус Одесе, и њену „библијску путеност”. 
холистичке анализе. У савременом, данас важећем болоњском курикуларном поимању наставног предмета, књижевност се схвата као многополарна културна синтеза. Шта ли би на то рекли наши професори? Да ли би поверовали да коначно нема освртања на ригидну скалу совјетско-антисовјетско, да су на културолошкој сцени, коначно, најважнији новаторство и нонконформизам? Или би рекли да је све исто као и пре, само са супротним предзнаком.

Одиста, ово јесте доба узвраћања многих удараца, можемо рећи и извесног ресантимана. Религија се евидентно вратила у животно важне токове, и тај глобални постсекуларни процес није могуће игнорисати. У оквирима руског културног поља сада активно делује и хришћанство, и ислам, и будизам, и јудаизам... Као преводилац савремене књижевности развила сам чуло за дискурсни конгломерат (када се реч Бог пише малим словом: б-г) и примећујем да захтев за маскулином идеолошком монолитношћу (Захар Прилепин) изазива нервозу једног дела читалишта. Феминино подривање тог монолита (Татјана Толстој, Људмила Улицка, Светлана Алексијевич) изазива пак нервозу другог дела. Укратко, приметна је тенденција активног повратка религиозне тематике, уз реактивно јачање улоге културологије. То се односи како на књижевност, тако и на науке о књижевности, а напосе на педагогику, на програме школа и факултета. Наиме, вредносно-културолошка педагогика чини се најпримеренијом конфесионално неједнородном друштву, у оквиру методолошког потенцијала културологије заговара се мирна коегзистенција верника свих конфесија, па и неверујућих људи и агностика. ${ }^{2 *}$

Ипак, како прећутати или миноризовати чињеницу да је Русија формирана као монорелигиозна, притом православна, култура? Учење о врлини, добру и злу, одвајање лепог од ружног, истине од лажи, суштинска евангелизација руске културе тим пре се не да прећутати. Оно што одликује руску уметничку књижевност, од њених почетака у знаку примања хришћанства па све до данас, по много чему се уписује у провиденцијални наратив, што поништава „суботњу” плотску пропадљивост у име недељне, „васкршње” непропадљивости пнеуме. Најлакше је то показати и доказати управо на материјалу руске књижевности. Водећи своје јунаке од пуког таворења ка пуном духовном постојању, руска књижевност познаје, тим пре, и јунаке који остају слепи за ту шансу.

2 Увођење религиолошких садржаја у школе Руске Федерације, у виду основа духовно-моралног васпитања, почело је 2010. године. Методологија презентовања материјала је културолошка, без конфесионалне индоктринације. Предмет Основе йравославне кулйуре потиснут је предметом Основе релиїиозних кулйура и свейовне ейике. На делу је одрицање од неоклерикалних утопија, ради избегавања етно-конфесионалних конфликата. 
Ружни, зли, банални, обезбожени гестови понајпре бивају поражени у христоликом свету романа Достојевског - његови јунаци, у финалу који није увек отекстовљен, дакле у неком вероватном свету, добијају прилику да се покају, искупе, препороде. Овај „сурови” таленат свакој људској ваши, која пишти из свог подземља, нуди могућност амнестије. Многи његови одвећ телесни јунаци стигматизују се духом, па макар он био анаграмски скривен (рецимо у презименима: проститутка Барашкова, самоубица Ставрогин, убица Раскољников).

Неки од њих се оглашавају као песници или поштоваоци поезије. Њихова дела и њихову лектиру диктира нужност васпостављања боголикости човека. Региструјемо њихову распетост, између ниске садржине и високе форме (или обрнуто). Сетимо се Младићевих и Аглајиних сањарија док читају Пушкина, Митјиних суза над Шилером, Иванове „Легенде о великом инквизитору”, Смердјакова и његових тлапњи, „вапаја” Видопљасова, расправа Раскољникова, Опискина, Кармазинова, Петра и Степана Трофимовича, стихова капетана Лебјаткина, најзад.

Сви ти јунаци продукују поезију, осцилирајући између бурлеске и травестије, са подразумевањем великог и вредног контекста и подтекста, посредно указујући на антипоетичност дате епохе. Програм те „лоше” поезије, а понајпре у контексту великих романа Достојевског, и још шире у мегатексту руске књижевности, јесте указивање на десакрализацију света.

Било је то време продора идеја дарвинизма, и респективног песничког модернитета, који долазе на смену средњовековним концептима. Дарвин у предговору своје књиге о природној селекцији, објављене средином 19. века, указује на неодрживост хришћанског морала, који налаже да се јаки жртвују за слабе, добри за зле, здрави за болесне. Било је изазовно преустројити свет по начелима природног одабира, када преживљавају најјачи, по цену међусобног истребљења. Тако груба проповед социјалног дарвинизма иритирала је Достојевског, он јој упорно супротставља хришћанску дијалектику, и кажњава лудилом, робијом, смрћу оне који су се дрзнули да на себи провере гесло „ако Бога нема све је дозвољено”. Обезбожени свет приказан је као чаша пуна „мувождерства". Сви ти инсектоидни јунаци руске књижевности, који настањују и совјетску (песме Николаја Олејникова) и најновију уметничку продукцију (кратке прозе Виктора Пељевина), трагају за брешом у зиду, сневајући о оностраној препородној слободи (Рамадански, Руска књижевна инсекйомахија, у штампи).

Отуда није чудо што је у састављању Анйолойије руске йриче 20века (приредили Миливоје Јовановић и Владимир Меденица, 2004) преовладао митопоетски увир сваког иоле значајног руског штива. Све поетичке разлике око осамдесет аутора нанизане су у једну причу, са 
тачно одређеним секвенцама: Caga, каgа сам се йробуgио (од Сологуба до Хармса), На йола йуй $а$ gо Месеи, (од Паустовског до Војновича) и Бубан за іорњи свети (од Белова до Ј. Садур). То су заправо речите насловне ситагме дела Валерија Брјусова, Василија Аксјонова и Виктора Пељевина, промовисане у формулу припадајућег поетичко-генерацијског дешавања у оквиру једновековног руског кратког наратива. При чему се то дешавање своди на тезу да спасење за изабране појединце-ствараоце, долази из трансценденције, док друге визије слободе трпе неуспех. Пред нама је високохармонизовано уланчавање оделитих епохалних наратива. Уметничка нарација, пак, поготово она из позадине, уме и да изненади а не само да потврди антологичарева очекивања. Ако је трагање за смислом постојања заиста у врху интересовања одабраних аутора руских прича, то се зацело односи и на писце другог ешалона. Кузмина, али и изостављеног Харитонова, Шаламова, али и изостављеног Параџанова, Сирина, али и изостављеног Ивањикова? Олге Комарове и њеног Херцбрудера? Писци са маргине, рекло би се, суштински модификују наднаратив звезда ове атологије, и ако хоћете утерују га у лаж, на начин неизбежне квари-игре. Да ли је у датумски последњем опусу антологије одгонетнута шифра неке неспорне трајекторије, или нас је антологија довела у слепу улицу, настањену наративима које стварност пориче, ако другачије не, а оно - „ћутањем народа”? Културолошки пледоаје данашњице посвећен је експерименталним, маргиналним, тајним, азилантским, рукописима, чији аутори могу бити и међусобно завађени. Они подривају сваки смисао, а поготово онај политкоректних квазиутопија.

Ваља младог читаоца провести кроз сцилу и харибду старих бинарних дистинкција, између идеалног и стварног, духа и тела. И потестарну имагологију, која је дуго била доминантна шифра руске књижевности (ах, ти Пољаци) ваља сада диференцирано очитавати. Кохезивно начело унутар групе је, свакако, највиша вредност за један народ. Међутим, који концепт протежирати, да ли конзервативни или радикални? Да ли послушност или непослух? Очеве или децу? Отуда је важност руског постмодернизма енормно велика са становишта испражњеног модела утопије и револуције. То је побуна, додуше скрштених руку, која не мора обавезно да води у суноврат старих вредности, пред агресијом новог а невредног. Битан је дијалог, тестирање, суочавање, јукстапозиција.

Наши студенти упознају соцреализам кроз филтер соцарта, кроз постмодернистичку цитатност Пригова, Рубинштајна, Сорокина и Пељевина, у полемичкој спрези са будизмом и конзумеризмом. Данас, у озрачју самиздатског квазипанегирика Абрама Терца (Что такое соииалистический реализм) студент има прилику се разабере у родослову ове епохалне формације, да откопа први, други, трећи и ко зна који култу- 
ролошки стратус његов, па и да се сензибилизује на детекцију идеолошког кича.

Мада управо у култури обично видимо израз људске слободе (насупрот тлачењу од стране економије и политике), чувар наше слободе налази се у несвесном, заснован на биологији а не култури: једино се кроз Ид ослобађамо свих окова. Интернет је добар савезник тако схваћеног фројдизма. Многоаспектни историографски наратив даје прилику да се генијални спев о Игоревом погоду тумачи (и) као надинвестиција велеиздаје (оцеубиство), баш као и убитачни, бирани стил Андреја Курбског. Норманизам, осијанизам, окултни наративи, евроазијство, ордија, јосифљани, Хазари, смута, Мазепа, космополити, све су то данас вишеструко културолошки реконцептуализовани феномени, и тешко је прописати само једно нормативно њихово тумачење.

Поменимо у том смислу индикативну серију Без глянц, а, која нуди монтажу мемоарског материјала, писама, успомена удовица и слично, не би ли прописно демистиковала нашу слику о великанима духа. Евидентна је доступност неизнивелисаних информација (о Њекрасову коцкару, Фету каријеристи, Тјутчеву егоисти, Пушкину обавештајцу, Достојевском панегиристи, Толстоју секташу, о мизогином, некрофилном, педофилном, каквом све не Песнику). Речју, пред тврдњама типа „Пушкин је Дима”, „Кутузов је жена” студенти ваља да користе филтере доброг укуса.

Коауторски уџбеник Р. Вајла и А. Гениса из раних деведесетих Роgная речь први је понудио дезидеологизовано, скоро фамилијарно дајџестирање ремекдела руске књижевности. Са нескривеним реторичким мајсторством емигрантски двојац наоштрио се против совјетске уџбеничке рутине. Такав приступ дакако да је био хладни туш, на начин руског глагола освежевать. Убијање идеолошке хеуристичке традиције вршило се у име непревреле, журне реформулације, када је све добродошло, само да заљуља темеље једне осведочено идеолошке утврде. О легитимности таквих полемичких захвата, истина другим поводом, писао је Михаил Гаспаров. ${ }^{3}$

3 „Руска култура се, почев од Петровог доба, развијала веома убрзано, прескачући степенике, не би ли сустигла Европу. Кад Шекспир доспева у оптику романтизма, Пушкинов Борис Гояунов испада двоструко краћи од сваке Шекспирове трагедије. Док

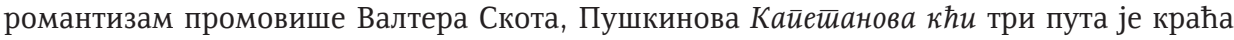
од сваког Скотовог романа. Романтизам мења однос према антици, а Пушкин прави превод Из Ксенофана Колофонскоі - преполовивши оригинал. Техника Пушкинових скраћивања изучена је: он чува структуру предлошка и оштро редукује детаље. Ту помислим, а зар су се времена тако променила? Руска књижевност и данас заостаје за европском приближно за једно или два поколења. Она и данас осећа потребу за брзометним, конспективним усвајањем европског искуства. Зар јој, онда, нису потребни и конспективни 
На то је потом заличио и Акуњинов фандорински серијал, који је романескно ревидирао читаву историју руске империје, малициозно указујући понајпре на пропуштене шансе да се „буде као сав остали свет". Јунак усмерен на лични упех вазда је, међутим, у Русији доживљаван као одурна фигура. Још од Андреја Болконског херојски песимизам је једина достојна варијанта понашања Обломов нам је убедљиво симпатичнији од Штолца. Чак су и „шездесеташи потискивали своју љубав према животу, настављајући са својом имитацијом бриге" (В. Новиков, О. Новикова, http://magazines.russ.ru/zvezda/2007/1/no17.html). И ту акуњински апостериорни гламур мало шта може да промени.

Руска хришћанска хуманистичка академија из Санкт Петербурга (Фонтанка, 15) увела је концепт методичке полифоније са мером, укусом и знањем, још пре масовне дигитализације (од раних деведесетих). Пре свега мислимо на едицију Pro et contra из серије Руский путь, која представља раскошну антологију критичких рефлексија о бројним ауторима. Рецимо да сличну платформу многогласне, додуше непрофесионалне, критике данас негује Фејсбук.

Студенти русистике, тако, већ више од двадесет година имају привилегију да опусе великих писаца и интелектуалаца (до сада преко сто), које је скоро немогуће једнозначно дефинисати, упознају и осмишљавају уз помоћ ове серије. Наведимо неке руске ауторе који су обухваћени овом едицијом: Д. Андрејев, А. Бели, Ахматова, Бахтин, Берђајев, Блок, С. Булгаков, Буњин, 3. Хипиус, Гогољ, Горки, Гумиљов, Љермонтов, Мајаковски, Мерешковски, Набоков, Пушкин, Розанов, В. Соловјов, Л. Толстој, Тјутчев, Чаадајев, Чернишевски, Чехов; ту су и Петар Велики и Катарина Велика, и појаве као што је словенофилство, православље.

Серију одликује свестрано откривање одређених опуса, предочаваем историје њихове рецепције, доксолошких обрта и превредновања, историје осмишљавања феномена, дијалошког јединства културе, суме руског самопоимања, свода различитих тачака гледишта, непоновљиве атмосфера епохе, освајања потиснутог и заборављеног наслеђа, успомена савременика, преписке, уникалних докумената. Електронска верзија

преводи - лирски дајџести, поезија у пилулама? Тим пре што конспективна лирика има тако моћно средство за скраћивање, као што је то верлибр (...) Може ли се тврдити да је управо лаконизам - универзална црта поетике 20. века? Зацело не: век је разнолик. Али то је црта макар једне поетичке тенденције овог века - оне која потиче из 1910-их, када је почињао имажизам, и када је Езра Паунд написао чувену песму од четири речи - кондензат читаве раногрчке лирике: 'Spring-Too long-Gongyle.' (Гонгила - име Сапфине ученице, изгубљено у њеним папирусним фрагментима). Краткоћа се доимала као протест против реторике - мада је, ако ћемо право, и она исто реторика, само другачија" (Гаспаров, 2001, 189-194). 
сваке књиге доступна је на интернету и на компакт дисковима. ${ }^{4 *}$ Треба истаћи да је овај приступ начелно другачији од дуговечног, али помало застарелог модела ЖЗЛ, који носи печат менталности само једног тумача.

У тексту После буgућносии и или настианак арјерїарgе (у саставу српског твотомног зборника После буgућносиии, суgбина иосиимоgерне) Михаил Епштејн своја запажања о последња два века руске књижевности синтетише у својеврстан периодни систем. Предлаже поделу на четири циклуса, чије рубне године изгледају овако: 1730-1840, 1840-1920, 1920-1990, 1990- . Сваки од њих са своје стране има по четири фазе: социјалну, моралистичку, религиозну, естетичку. Као пример како ова периодизација функционише рецимо да по њој Гумиљов, Мандељштам, Хлебњиков спадају у четврту, естетичку, фазу другог циклуса, док Мајаковски спада у прву, социјалну, фазу трећег циклуса. Најсавременију књижевну појаву у време конципирања овог система, 1990. године, Епштејн означава као apjepīapga и смешта је у последњу, естетичку фазу трећег циклуса. Патосу авангардног преиначавања на смену долази арјергарда са својом аморфношћу и метафизиком ђубришта. У есхатолошкој перспективи часније је - и естетички продуктивније - не бити први него последњи, не оглашавати се већ сашаптавати, не предводити него бити на зачељу (Епштејн 2010: 270-279).

Четврт века након свог оглашавања, периодни систем Михаила Епштејна је умногоме демонстрирао ваљаност својих прогностичких капацитета. Епштејн се чак осмелио да „мендељејевски” предвиди особине прве фазе четвртог циклуса руске књижевности, назвавши је „нова социјалност".

Судећи по изјавама Захара Прилепина али и одликама његове прозе, рекло би се да се руска књижевност још увек налази у тој, социјалној фази, четвртог циклуса. Савремена руска књижевност се надахњује идеалима „нове озбиљности”, патосом одговорности, дужности, мисије. Наступила је својеврсна мобилизација традиције у оригиналном кључу. Термин „нови руски реализам”, који предлажу неки критичари па и сами протагонисти књижевног процеса, као формула савременог књижевног процеса се, међутим, тешко прима, јер многи не желе да виде себе као настављаче некада славне али компромитоване традиције. Лудистички пројекат и логика уметничког гностицизма нису се исцрпли и предали...

${ }^{4}$ Парадоксално, дигитална информација рањивија је од папирне: због брзе смене производне технологије, масиви ових информација нетрагом настају у делићу секунде. Стога један од корисних издатака наших студената може бити наббавка што већег броја књига са препознатљивим логом на корицама. 
Последњих година се у руској уметничкој критици заузврат афирмисао термин йрансаваніарga, који је пре тридесетак година Акиле Бонито Олива применио на италијанске неоекспресионистичке сликаре. По речима руског теоретичара А. Е. Јермолина „трансавангарда је хронолошки поставангарда, али то је такво „пост” које постоји у ситуацији неуништивог уметничког плурализма".

Реконцептуализација устаљене књижевно-теоријске и књижевно-историјске таксономије као да не зна за границе. Исходећи из своје чувене културолошке карактерологије, Вадим Рудњев авангардисте и модернисте убраја - у различите карактеролошке типове. Први су тзв. епилептоиди (Мајаковски, Буњуел, Дали) а други - аутисти (Џојс, Пруст, Кафка). Руднев респективно сматра да је читава култура управо њихова творевима. Једна од његових занимљивијих поставки јесте да реализма у књижевности нема и не може бити, и да је све што се у тој сфери дешава, заправо, у знаку модификација романтизма. Још много смелих и духовитих хипотеза можемо наћи у његовом Енииклоиееијском реинику кулйуре 20. века, који одавно чека да се објави и у српском преводу.

У својству надвладавања сваког методолошког догматизма поменимо некомерцијални образовни пројект Arzamas, посвећен хуманистичким знањима, вођен амбицијом пружања што је могуће већег избора релеватних података на дату културолошку тему, уз успутне учинке депатетизације и (само)критике. То је својеврсни универзитет који расте на наше очи, окупљајући врсне стручњаке и предаваче из историје, књижевности, уметности, антропологије, филозофије - у предавањима, «пушкицама», шарадама, питањима и одговорима (Д. Биков, А. Архангељски, А. Жолковски, О. Лекманов, А. Лифшиц, А. Немзер и др.). Поменимо као куриозум титулу Александра Данијела, која на руском звучи овако: „исследователь инакомыслия в СССР”. Руска култура може и треба да издржи и таква игрива, „лицејска” зачикивања. Сваког четвртка нуди се ново 15-минутно предавање, презентовано у видео-формату, снабдевено различитим илустративним материјалом (чланци, фотогалерија, фрагменти филмских хроника, цитати из књига и интервјуа, карте, речници, архивски документи, мнемотехички дијалошки менији).

Монолошки, аукторијално конципирани уџбеници данас су изгубили своју оперативност - поставши нужно јеgан оg извора информација, знања, података, вредносног полазишта. Трокњижје огледа из руске књижевности 19. и 20. века Јеврема Бјелице (постхумно објављено 2017. године, у репрезентативном издању и компетентној редактури Татјане Јововић, те скрупулозно сврстано у „црногорску публицистичку русистику") свакако је надмашило првобитни ауторски концепт (пригодни текстови и фељтони публиковани за живота аутора, у предкомпјутерској ери). Оглашавајући се као ученик а не учитељ, нужно тран- 
килизујући драматичну културолошку буку, Бјелицин опус делује као закаснели гост. Мада је пред нама неспорно „огроман и ентузијастичан труд, оплемењен љубављу према одабраним темама" (препорука са корица), изгужване плахте поклоничких страсти читалац ће потражити на другом месту, рецимо у књижевној ложници Јасмине Ахметагић. У области наше књижевнотеоријске русистике њена књига о Достојевском (о злостављачу и жртви) једно је од лепших изненађења последњих година. Огласивши се непатвореним жаром (неретко и на рачун недовољне русистичке обавештености), критичарка се посветила појавама које воли, цени и препоручује. У условима када наши студенти немају као обавезан предмет теорију књижевности, њени радови посвећени руским темама прави су мајдан храбрих методолошких захвата и изграђеног личног става. Све књижевне јунаке достојевскијанског круга она је спремна да подвргне продуховљеном принципу етичке селекције: шта је човек кадар да учини пред самим собом (у својству безименог подвига) а шта је спреман да учини пред другима (у знаку охолости и разметљивости). У позадини ове, руској књижевности итекако прирођене дистинкције (ауторка уводи термин „лажни селф”) максималистички је етички императив, из кога имају потећи самозатајни гестови милосрђа и доброте.

Из области дијахронијских вештина сматрамо да је уџбеник Исйорија рускоі книневног језика (ирквенословенско-руска иреилитиаюа), Београд, 2016, понудио модел за углед, са информативним и аксиолошким оптимумом, исцрпном препорученом литературом али и отварањем питања за размишљање. Препустити реч тиму стручњака под надасве компетентном редактуром (др Ксенија Кончаревић) зацело је прави рецепт за презентацију сложеног филолошког градива (уз неизбежну дилему: да ли упослити филолошки или антифилолошки приступ, да ли приближити себе тексту или текст себи?). Филологија јесте комплексна интерпретација текста али пре свега - његових историјски коректних смислова. Премда је универзитетско-академска филологија постала интедисциплинарна наука, која настоји да актуелизује свој предмет, нужно је знати по чему је одређени текст био актуелан у време његовог настанка.

У условима данашње сарадње филологије и технологије (фундаментална електронска библиотека, машински превод, тренутна атрибуција текстова, електронски речници и провера правописа) повећава се информатичка култура специјалисте-филолога. То налаже и нове дидактичке, педагошке, докимолошке сценарије за припаднике нових генерација, баш као и нови стил учења и живљења. 


\section{ЛИТЕРАТУРА}

Анйолоїија руске ӣриче 20. века (ур. М. Јовановић, В. Меденица), том 1-3, Београд, Плато, 2004.

Ахметагић, Ј., Кюиїа о Досйојевском, Болесй ирекомерних сазнања, Београд, Дерета, 2013, 214 стр.

Бјелица, Ј., Оїлеgи о руској књижевностии 19. вијека, том 1-2, Подгорица, Завод за уџбенике и наставна средства, 2017, $334+428$ стр

Бјелица, Ј., Оїлеgи о руској књижевности и 20. вијека, Подгорица, Завод за уџбенике и наставна средства, 2017, 502 стр.

Bojn, R., Kultura i svetski sistem, http://www.fabrikaknjiga.co.rs/rec-71-17/

Бурлака, Д.К, Ценностно-культурологическая пеgагогика: путь развития толерантности в конфессионально неоянородном обществе http://rhga.ru/ about_us/rector/0430.pdf

Бурлака, Д.К., Способно ли травославие стать культурообразующим фактором развития российского образования? http://rhga.ru/about_us/ rector/2\%201998.pdf

Бурлака, Д.К., Русский путь: от совокупности фрагментов к системе, httр:// rhga.ru/about_us/rector/044C.pdf

Валлерстайн, И.М., Миро-системный анализ http://www.nsu.ru/filf/rpha/papers/ geoecon/waller.htm

Valerštajn, I., Kultura kao ideološko poprište modernog svetskog sistema, http://www. fabrikaknjiga.co.rs/rec-71-17/

Valerštajn, I., Kultura jeste svetski sistem, odgovor Bojnu, http://www.fabrikaknjiga. co.rs/rec-71-17/

Вигурский К.В, Пильщиков, И.А., Информатика и филология (проблемь и перспективы взаимоgействия) http://feb-web.ru/feb/feb/media/200307_elbib. htm?cmd=show

Гаспаров, М., Записки и выписки, Москва, Новое литературное обозрение, 2001, 415 стр.

Епштејн, М., После буgућносйи, суgбина йосймоgерне, том 1, Београд, Драслар партнер, 2010, 302 стр.

Ермолин, Е. А., Трансавангарg как параяигма современной литературы, Филологический класс, 2011/25

http://cyberleninka.ru/article/n/transavangard-kak-paradigma-sovremennoy-literatury

Кончаревић, К., Перкучин С., Марковић, М. и Рељић М., Истиорија рускої кюижевной језика (ирквенословенско-руска итрейлийања), Београд, Јасен, 2016, 213 стр.

Marčetić, A., O novoj komparatistici, Beograd, Službeni glasnik, 2015, 219 str.

Моретти, Ф., Дальнее чтение, Москва, Издательство Института Гайдара, 2016, 352 c.

Moretti, F., Distant reading, London-New York, Verso, 2013, 244 pp

Нестеренко, М., Своевременные мысли, Октябрь, 2016/11 http://magazines.russ. ru/october/2016/11/svoevremennye-mysli.html 
Новиков, В., Новикова, О., Филипп Киркоров и Дмитрий Быков, или Феноменология вторичности, Звезда, 2007/1 http://magazines.russ.ru/zvezda/2007/1/ no17.html

Пильщиков, И., „У цифровой филологии большое будущее” (разговор: Кирилл Головастиков, Ирина Калитеевская), http://arzamas.academy/ materials/1161

Рамадански, Д., Руска књижевна инсекйомахија, Нова зора, Билећа - Гацко 2017/јесен, у штампи

Руднев, В., Энииклопеgический словарь культуры ХХ века, Москва, Аграф, 2009, 544 стр.

Draginja Ramadanski

\section{METHODICAL UNCERTAINTIES FROM THE TIP OF THE ICEBERG}

\section{Summary}

How to teach the Russian literature today, being focused on the screen, from which we are bombed with rather contradictory opinions? Both students and teachers are aware of the methodical dead end they are in. Although the technological advantage is on students' side, it is expected that the teacher keeps the situation under control. The answer we are trying to find out is not, however, pessimistic. Besides the insight into today's practice, it implies a recall of our teachers "before the network", pointing out the contemporary examples as well as suggestions for the future.

Key words: digital humanities, arbitrary tutorials, global mega-narrative, collection of specialist approaches, history of interpretations 